International Journal of Current Advanced Research

ISSN: O: 2319-6475, ISSN: P: 2319 - 6505, Impact Factor: SJIF: 5.995

Available Online at www.journalijcar.org

Volume 6; Issue 4; April 2017; Page No. 3295-3296

DOI: http://dx.doi.org/10.24327/ijcar.2017.3296.0253

Research Article

\title{
AWARENESS ON BLOOD TRANSFUSION AMONG DENTAL OUTPATIENTS
}

\section{SaiSandhya.T and GowriSethu}

Saveetha Dental College, Chennai, TamilNadu, India

\section{A R T I C L E I N F O}

\section{Article History:}

Received $16^{\text {th }}$ January, 2017

Received in revised form $10^{\text {th }}$ February, 2017

Accepted $22^{\text {nd }}$ March, 2017

Published online $28^{\text {th }}$ April, 2017

\section{Key words:}

Blood Transfusion, Awareness Of Blood

Donation

\begin{abstract}
A B S T R A C T
Aim: To improve awareness of blood transfusion among dental outpatients.

Objective: To measure the level of knowledge regarding blood donation,find out positive and negative attitudes suggest some motivational factors.

Background: Understanding the knowledge and awareness of blood donation among dental outpatients is important as blood is important resource of life and blood donation is life saving.
\end{abstract}

Copyright $@ 2017$ SaiSandhya.T and GowriSethu. This is an open access article distributed under the Creative Commons Attribution License, which permits unrestricted use, distribution, and reproduction in any medium, provided the original work is properly cited.

\section{INTRODUCTION}

"More blood, more life" this was the theme for World Donor Day 2011 on the $14^{\text {th }}$ of June to emphasise the critical need for more people all over the world to become lifesavers by donating blood regularly(1).Donating blood can be lifesaving for persons who have lost large amounts of blood because of serious accidents, new medical and surgical procedures, civil conflicts and military wars as well as for patients who have become severely anemic because of serious haematological diseases on treatments such as cancer therapy(2).Therefore availability of blood is an important concern to the society(3).Increase in the level of awareness and positive attitude towards blood donation is the highest priority of all blood transfusion centres(4). The most prominent reason on why people give blood is altruism beside community needs and support, family assurances and social pressure(5).On the other hand fear, lack of knowledge and inconvenience have been described to be the primary obstacles to donation(6).

\section{MATERIALS AND METHODS}

A self created questionnaire was given to 30 participants. The questionnaire contained knowledge based (5 questions), practice (5 questions) and few motivational questions. Questionnaires needed 10minutes to be completed. Filled questionnaires were collected at the same time and the responses are analysed statistically.

*Corresponding author: SaiSandhya.T

Saveetha Dental College, Chennai, TamilNadu, India

\section{RESULTS AND DISCUSSION}

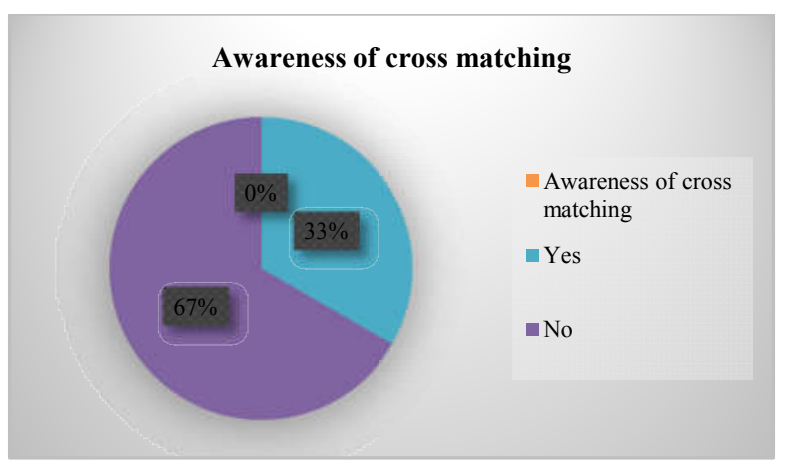

From the results obtained,it is observed that $83 \%$ of participants believe that blood transfusion is safe. $47 \%$ are aware of blood related diseases such as HIV.90\% knew the correct age for blood donation.33\% are aware of cross matching.

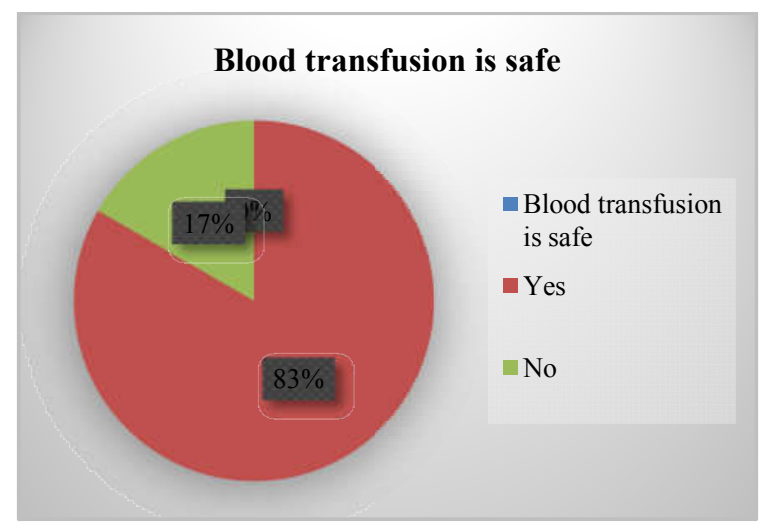




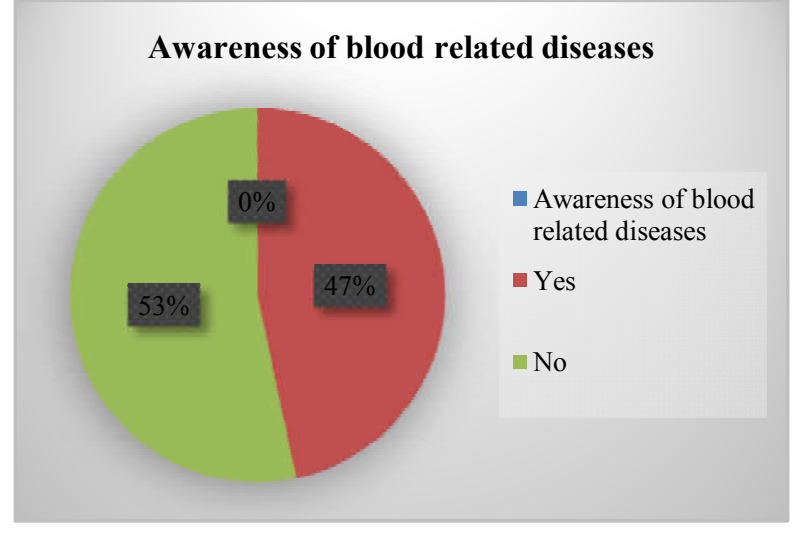

Correct age for blood donation

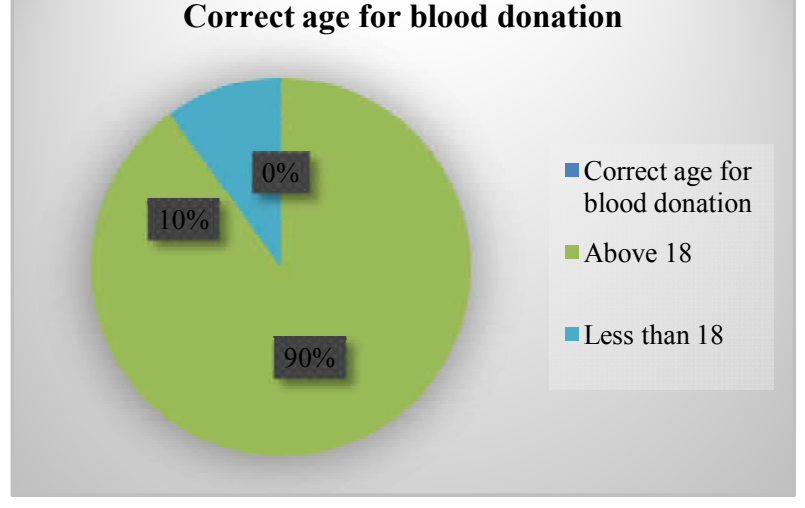

\section{CONCLUSION}

The knowledge and awareness of blood transfusion is adequate among the participants. It may be concluded that regular awareness programmes on various aspects of blood donation should be conducted so that needy people gets the blood at the appropriate time.

\section{References}

1. Knowledge, attitude, practices and factors associated with voluntary blood donation among university students in Kilimanjaro, Tanzania. Elias E, Maura W, Philemon R M, Damian D J, Mahande M J.

2. Manikandan S, Sri Kumar, Ruvanthika, A study on knowledge, attitude and practice on blood donation among health professionals in Chennai, Tamil Nadu.

3. Al dress A M,Attitude beliefs and knowledge about blood donation and transfusion in Saudi population, Pak J med

4. Knowledge and awareness among nurses regarding the blood transfusion services and practices in a tertiary care teaching hospital.Talali S.GuptaA K, Asian $J$ transfusion sci.2016

5. Attitude toward blood Donation among medical and non medical students across Karachi, Anwer M OU I Fawwad.

6. Voluntary blood donation among students-A cross sectional study on Knowledge and practice vs attitude. Raghuwanshi B., Pehlanjani

\section{How to cite this article:}

SaiSandhya.T and GowriSethu (2017) ' Awareness On Blood Transfusion Among Dental Outpatients', International Journal of Current Advanced Research, 06(04), pp. 3295-3296.

DOI: http://dx.doi.org/10.24327/ijcar.2017.3296.0253 